\title{
Influence of Roseday-5 tablet on corrosion resistance of SS 316L in artificial saliva
}

\author{
N. Karthiga, ${ }^{1 *}$ J.M. Praveena, ${ }^{1}$ A. Deepika, ${ }^{1}$ A.J.A. Fathima, ${ }^{1}$ \\ R. Bhuvaneshwari, ${ }^{1}$ G.D. Christina, ${ }^{1}$ V.D. Mary, ${ }^{1}$ N. Renuga Devi, ${ }^{2}$ \\ T. Umasankareswari ${ }^{3}$ and S. Rajendran ${ }^{1 *}$ \\ ${ }^{1}$ Corrosion Research Centre, Department of Chemistry, St Antony's College of Arts and \\ Sciences for Women, Dindigul-624005, India \\ ${ }^{2}$ Department of Zoology, GTN Arts College, Dindigul-624005, India \\ ${ }^{3}$ Department of Chemistry, Rajapalayam Raju's College, Rajapalayam, India \\ *E-mail: susairajendran@gmail.com, venkatuma91@gmail.com
}

\begin{abstract}
Regularly grown teeth lead to beautiful and attractive smiles that will attract everyone. But some people have irregularly arranged teeth. These less fortunate people go to doctors to regularize the growth of teeth. The dentists in turn recommend the use of orthodontic wires, made of various alloys. In the oral environment in presence of saliva these wires undergo corrosion. Apart from this, these wires undergo further corrosion when we take various tablets, juices and food items. In the present work the influence of a tablet Roseday-5 mg, on the corrosion resistance of orthodontic wire made of SS 316L alloy, in artificial saliva has been evaluated. The corrosion resistance of SS 316L alloy in artificial saliva, in the absence and presence of Roseday-5 $\mathrm{mg}$ has been evaluated by polarization study and AC impedance spectra. Polarization study reveals that in the presence of Roseday-5 mg, $L P R$ value increases from 1973954 to $2053646 \mathrm{Ohm} \cdot \mathrm{cm}^{2}$. Corrosion current decreases from $2.245 \cdot 10^{-8}$ to $2.139 \cdot 10^{-8} \mathrm{~A} / \mathrm{cm}^{2}$. That is, in presence of Roseday-5 mg, the corrosion resistance of SS 316 L alloy in artificial saliva increases. AC impedance study reveals that in the presence of Roseday-5 $\mathrm{mg}, R_{\mathrm{t}}$ value increases from 320260 to $416460 \mathrm{Ohm} \cdot \mathrm{cm}^{2}$. The $C_{\mathrm{dl}}$ value decreases from $1.5925 \cdot 10^{-11}$ to $1.2246 \cdot 10^{-11}$ $\mathrm{F} / \mathrm{cm}^{2}$. That is in the presence of Roseday-5 $\mathrm{mg}$ the corrosion resistance of SS $316 \mathrm{~L}$ alloy in AS increases. It is concluded that people clipped with orthodontic wire made of SS 316L alloy need not hesitate to take Roseday- $5 \mathrm{mg}$ orally.
\end{abstract}

Keywords: artificial saliva, corrosion, Roseday-5, orthodontic wires, SS 316L alloy, electrochemical studies.

Received: April 1, 2020. Published: May 18, 2020

doi: $\underline{10.17675 / 2305-6894-2020-9-2-14}$

\section{Introduction}

Saliva is a watery substance formed in the mouths of animals, secreted by the salivary glands. Human saliva comprises $98 \%$ water, plus electrolytes, mucus, white blood cells, epithelial cells (from which DNA can be extracted), glycoproteins, enzymes (such as amylase and 
lipase), antimicrobial agents such as secretory $\operatorname{IgA}$ and lysozyme. The enzymes found in saliva are important in beginning the process of digestion of dietary starches and fats. These enzymes also play a role in breaking down food particles entrapped within dental crevices, thus protecting teeth from bacterial decay. Furthermore, saliva serves a lubricative function, wetting food and permitting the initiation of swallowing, and protecting the mucosal surfaces of the oral cavity from desiccation. Various animal species have special uses for saliva that go beyond predigestion. Some swifts use their gummy saliva to build nests. Aerodramus nests form the basis of bird's nest soup [1-4].

Corrosion resistance of various metals and alloys in artificial saliva in presence and absence of various tablets, food additives etc. have been investigated. Corrosion resistance of metals and alloys such as SS 316L, aluminum, nickel-titanium alloy in artificial saliva have been investigated $[5,6]$.

Kamiński et al. have investigated the effect of glow discharge nitriding on the corrosion resistance of stainless steel orthodontic arches in artificial saliva solution [7].

They have carried out a comparative study on orthodontic arch-wires AISI 304 steel before and after low temperature plasma nitriding. Polarisation study and AC impedance spectra have been employed for this purpose. Microhardness was measured before and after treatment.

The influence of snake fruit extract (Salacca zalacca) in inhibiting the release of chromium $(\mathrm{Cr})$ and nickel $(\mathrm{Ni})$ ion from stainless steel orthodontic wire to saliva has been investigated by Erwansyah and Susilowati [8]. $\mathrm{Cr}$ and $\mathrm{Ni}$ ion release was measured using atomic absorption spectrophotometry. The investigation was made on control group and treatment groups. Pre-tests and post-tests were conducted. It is evident from this study that Snake fruit seeds extract effectively inhibits the $\mathrm{Ni}$ ions release from stainless steel orthodontic wire at a concentration of $300 \mathrm{ppm}$.

Musa Trolic et al. have examined the influence of probiotic supplements recommended for use in orthodontic patients on the corrosion stability of stainless steel and three types of NiTi orthodontic wires [9]. The corrosion resistance was measured by polarization study and AC impedance spectra. It was observed that probiotic bacteria L reuteri and probiotic supplement influence on a general corrosion rate as well as on likelihood of pitting corrosion occurrence. It was also noticed that their effect is dependent on the type of alloy and coating.

316L Stainless steels are widely used in biomedical applications with respect to their excellent corrosion resistance, nonmagnetic properties, high ductility and acceptable biocompatibility. There have been made electrochemical studies in vitro in order to determine the corrosion reactions, which are necessary for foreseeing the behavior of the materials used in orthodontic applications. The degradation of metals and alloys in the human body is a combination of effects due to corrosion and mechanical activities. In dentistry, 316L stainless steel are used in a variety of applications: sterilized instruments, endodontic files in root canal therapy, metal posts in root canal treated teeth, temporary crowns, arch wires and brackets in orthodontics, a necessary condition for these applications must to resist to pitting corrosion [10]. 
In the present work corrosion resistance of SS $316 \mathrm{~L}$ in artificial saliva in presence and absence of Roseday-5 tablet has been investigated.

\section{Materials and methods}

\section{Preparation of the metal specimens}

A thin wire metal specimen namely SS 316L alloy is utilized as test material for this work. The chemical composition of the alloy is as follows: $18 \% \mathrm{Cr}, 12 \% \mathrm{Ni}, 2.5 \% \mathrm{Mo}, \mathrm{C}<0.03 \%$, and balance is Fe.

\section{Procedure}

The orthodontic wire was encapsulated in Teflon rod. Prior to the surface treatment, the specimens were subjected to surface polishing. They were degreased with trichloroethylene followed by mechanical polishing with different polishing papers (Course, Medium, Fine \& Extra fine). The specimens were rinsed with ethanol followed by distilled water and dried with a clean tissue paper. Finally the specimens were kept in desiccators until use.

\section{Preparation of artificial saliva}

The corrosion resistance of orthodontic wire made of SS 316L alloy in artificial saliva (AS) in presence of was used as corrosive medium to explore the inhibition potential of Roseday5 tablet was measured. The preparation of artificial saliva was done using the composition of Fusayama Meyer artificial saliva (AS). Artificial saliva was prepared in laboratory and the composition of artificial saliva was as follows: $\mathrm{KCl}-0.4 \mathrm{~g} / \mathrm{L}, \mathrm{NaCl}-0.4 \mathrm{~g} / \mathrm{L}$, $\mathrm{CaCl}_{2} \cdot 2 \mathrm{H}_{2} \mathrm{O}-0.906 \mathrm{~g} / \mathrm{L}, \mathrm{NaH}_{2} \mathrm{PO}_{4} \cdot 2 \mathrm{H}_{2} \mathrm{O}-0.690 \mathrm{~g} / \mathrm{L}, \mathrm{Na}_{2} \mathrm{~S} \cdot 9 \mathrm{H}_{2} \mathrm{O}-0.005 \mathrm{~g} / \mathrm{L}$, urea $-1 \mathrm{~g} / \mathrm{L}$.

\section{Roseday-5 $m g$}

Roseday-5 mg (ROSEDAY $5 \mathrm{M}$ ) tablet is used to reduce the level of bad cholesterol in the body. It is also used in the treatment of long-term complications such as heart disease or stroke. A proper diet and regular exercise should be maintained along with taking this medicine. Moreover, this medicine is used in reducing the amount of cholesterol in children and patients between 10 to 17 years of age suffering from hypercholesterolemia (a genetic disorder) [11].

\section{Potentiodynamic polarization study}

In the present study, Polarization studies were carried out in a CHI Electrochemical work station I analyzer, model 660A. It was provided with automatic iR compensation facility. A three electrodes cell assembly was used. The working electrode was SS 316L alloy. A saturated calomel electrode (SCE) was the reference electrode and platinum was the counter electrode. A time interval of 5 to 10 minutes was given for the system to attain a steady state open circuit potential. The working electrode and platinum electrode were immersed in artificial saliva in the absence and presence of inhibitor. Saturated calomel electrode was 
connected with the test solution through a salt bridge. From the polarization study, corrosion parameters such as corrosion potential $\left(E_{\text {corr }}\right)$, corrosion current $\left(I_{\text {corr }}\right)$, Tafel slopes $\left(b_{\mathrm{a}}\right.$ and $\left.b_{\mathrm{c}}\right)$ and linear polarization resistance $(L P R)$ were calculated. During the polarization study, the scan rate $(\mathrm{V} / \mathrm{s})=0.01$; hold time at $E_{\mathrm{f}}(\mathrm{s})=0$ and quiet time $(\mathrm{s})=2[12,13]$. Scan rate $(\mathrm{V} / \mathrm{s})$ refers to potential scan rate. Hold time at final $E$ (s) refers to potential hold time after the $1^{\text {st }}$ sweep segment. In $E_{\mathrm{f}}(\mathrm{s}), E_{\mathrm{f}}$ means final potential and "s" refers to second. Quiet time (s) refers to quiescent time before potential scan.

\section{AC impedance measurements}

Impedance is a measure of the ability of a circuit to resist the flow of electrical current, Electrochemical impedance is usually measured by applying an AC potential to an electrochemical cell and then measuring the current through the cell. Electrochemical impedance is normally measured using a small excitation signal.

AC impedance studies were carried out in electrochemical impedance work station analyzer model CHI 660A three electrodes cell assembly was used. The working electrode was used as SS 316L alloy. A saturated calomel electrode (SCE) was used as the reference electrode and a rectangular platinum foil was used as the counter electrode. AC impedance spectra were recorded after doing $i R$ compensation. The real part $\left(Z^{\prime}\right)$ and imaginary part $\left(Z^{\prime \prime}\right)$ of the cell impedance were measured in Ohms at various frequencies. The corrosion parameters such as charge transfer resistance $\left(R_{\mathrm{t}}\right)$ and the double layer capacitance $\left(C_{\mathrm{dl}}\right)$ were calculated. During AC impedance spectra recording, the amplitude $(\mathrm{V})=0.005$ and quiet time $(s)=2$. Quiet time (s) refers to quiescent time before potential scan. Amplitude refers to displacement. $C_{\mathrm{dl}}$ values were calculated using the following relationship.

$$
\begin{gathered}
R_{\mathrm{t}}=\left(R_{\mathrm{s}}+R_{\mathrm{t}}\right)-R_{\mathrm{s}} \\
C_{\mathrm{dl}}=\frac{1}{2 \cdot 3.14 \cdot R_{\mathrm{t}} \cdot f_{\max }}
\end{gathered}
$$

Where $R_{\mathrm{s}}$ is the solution resistance and $f_{\max }$ is the frequency at maximum imaginary impedance [14].

\section{Results and discussion}

Influence of Roseday-5 mg on SS 316L alloy

Analysis of potentiodynamic polarization study

Electrochemical studies such as polarization study and AC impedance spectra have been extensively used in corrosion inhibition study to know the mechanistic aspects of corrosion inhibition [15-19].

Corrosion resistance of SS 316L alloy in artificial saliva in presence of Roseday-5 mg is given in the Table 1. The polarization curves of SS 316L alloy immersed in various test solutions are shown in Figures 1 and 2. The linear polarization resistance value of SS 316L 
in artificial saliva in the absence and presence of Roseday-5 tablet is compared in Table 2 and graphically in Figure 3.

Table 1. Corrosion parameters of SS 316L alloy immersed in artificial saliva (AS) in the absence and presence of Roseday- 5 obtained by polarization study.

\begin{tabular}{cccccc}
\hline \multicolumn{1}{c}{ System } & $\begin{array}{c}\boldsymbol{E}_{\text {corr }} \\
\text { V }\end{array}$ & $\begin{array}{c}\boldsymbol{b}_{\mathbf{c}} \\
\text { V/decade }\end{array}$ & $\begin{array}{c}\boldsymbol{b}_{\text {a }} \\
\text { V/decade }\end{array}$ & $\begin{array}{c}\boldsymbol{L P R} \\
\mathbf{O h m} \cdot \mathbf{c m}^{\mathbf{2}}\end{array}$ & $\begin{array}{c}\boldsymbol{I}_{\text {corr }} \\
\mathbf{A} / \mathbf{c m}^{\mathbf{2}}\end{array}$ \\
\hline Artificial saliva & -0.483 & 6.143 & 3.667 & 1973954 & $2.245 \cdot 10^{-8}$ \\
AS+Roseday-5 & -0.476 & 6.133 & 3.764 & 2053646 & $2.139 \cdot 10^{-8}$ \\
\hline
\end{tabular}

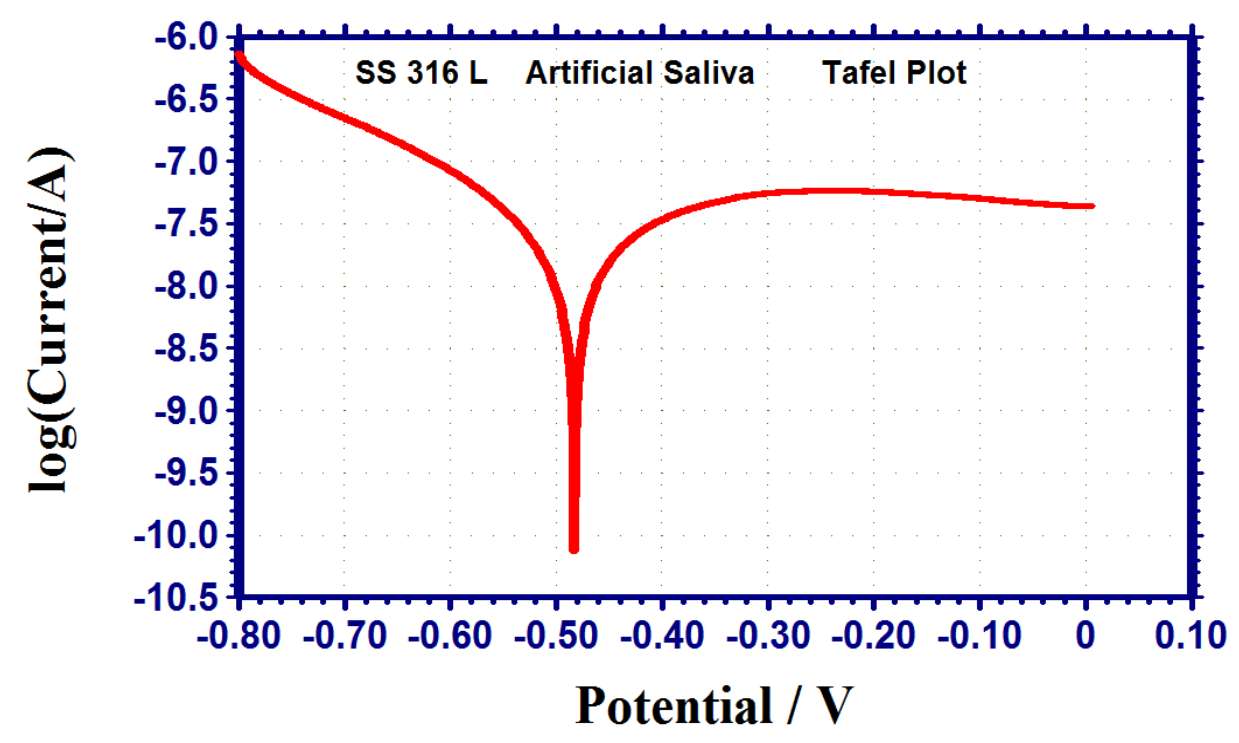

Figure 1. Polarization curve of SS 316L alloy immersed in artificial saliva.

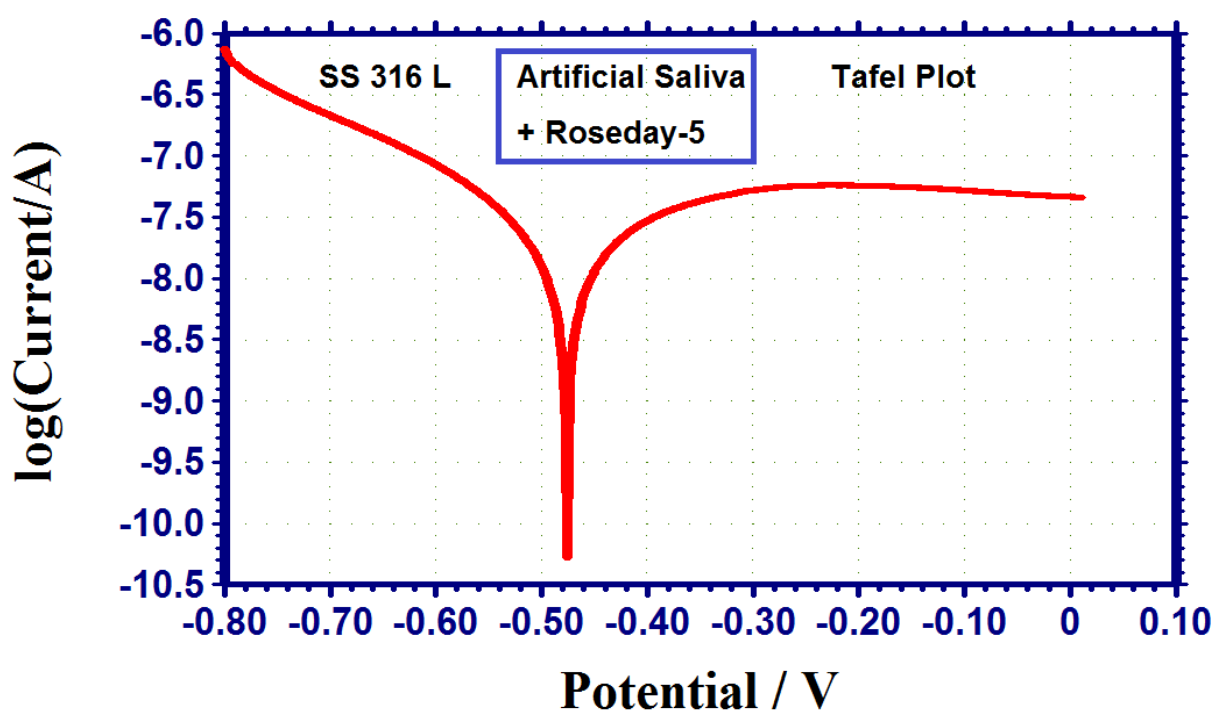

Figure 2. Polarization curve of SS 316L alloy immersed in artificial saliva in the presence of Roseday-5. 
Table 2. Comparison of linear polarization resistance in the absence and presence of Roseday-5.

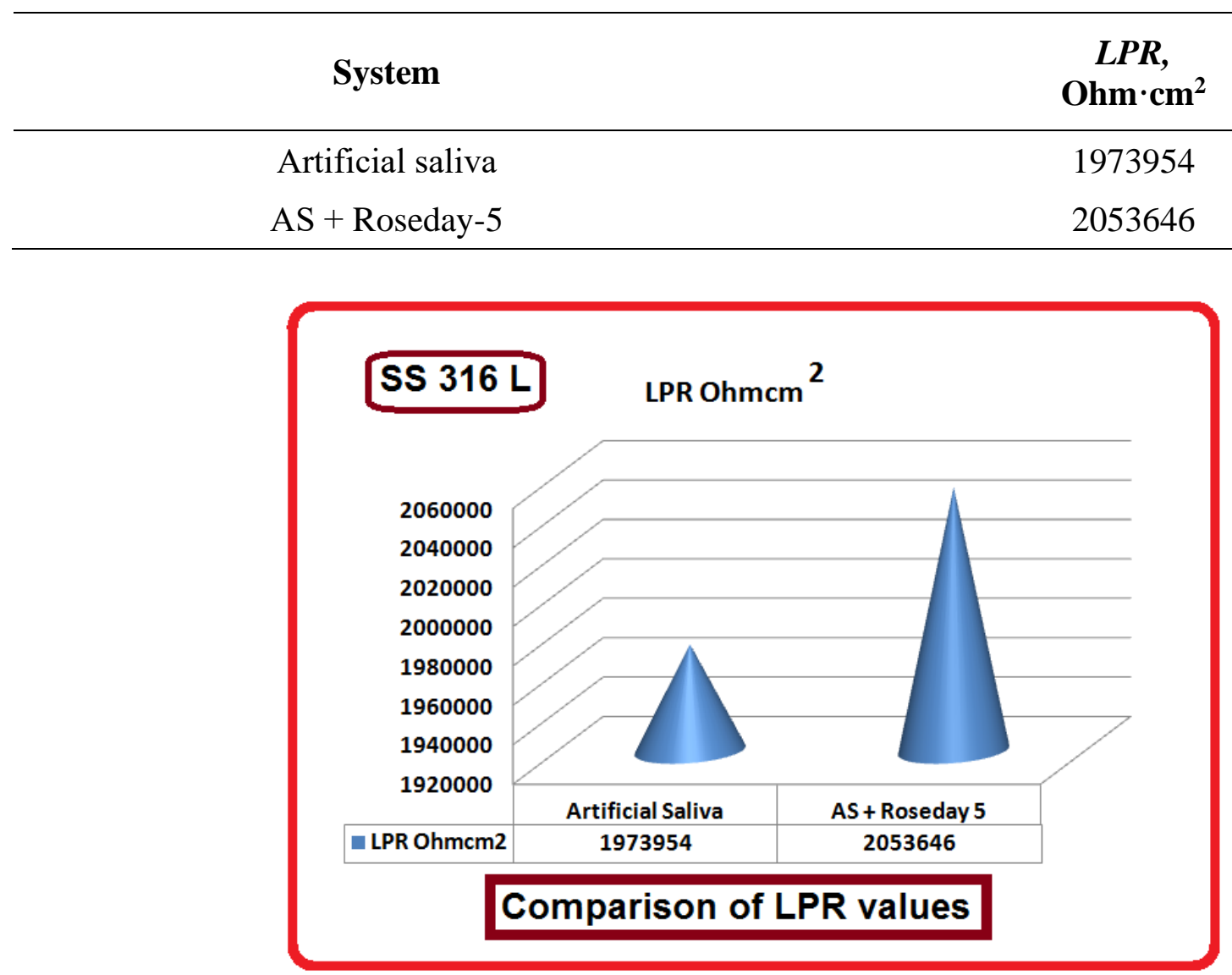

Figure 3. Comparison of linear polarization resistance value of SS 316L alloy in the absence and presence of Roseday-5.

When SS 316L alloy is immersed in artificial saliva, $E_{\text {corr }}$ (corrosion potential) is -0.483 . The corrosion current $\left(I_{\text {corr }}\right)$ is $2.245 \cdot 10^{-8} \mathrm{~A} / \mathrm{cm}^{2}$. Cathodic Tafel slope $\left(b_{\mathrm{c}}\right)$ is $6.143 \mathrm{~V} /$ decade. The anodic Tafel slope $\left(b_{\mathrm{a}}\right)$ is $3.667 \mathrm{~V} /$ decade. The linear polarization resistance $(L P R)$ is $1973954 \mathrm{Ohm} \cdot \mathrm{cm}^{2}$.

\section{Influence of Roseday -5mg as revealed by polarisation study}

When Roseday-5 mg is added to artificial saliva, the corrosion potential $\left(E_{\text {corr }}\right)$ is -0.476 . The corrosion current $\left(I_{\text {corr }}\right)$ is $2.139 \cdot 10^{-8} \mathrm{~A} / \mathrm{cm}^{2}$. Cathodic Tafel slope $\left(b_{c}\right)$ is $6.143 \mathrm{~V} /$ decade. The anodic Tafel slope $\left(b_{\mathrm{a}}\right)$ is $3.764 \mathrm{~V} /$ decade. The linear polarization resistance $(L P R)$ is $2053646 \mathrm{Ohm} \cdot \mathrm{cm}^{2}$.

It is observed from the Table 1 that when Roseday $-5 \mathrm{mg}$ is added to AS, The $L P R$ value increases from $1973954 \mathrm{Ohm} \cdot \mathrm{cm}^{2}$ to $2053646 \mathrm{Ohm} \cdot \mathrm{cm}^{2}$. The corrosion current decreases from $2.245 \cdot 10^{-8}$ to $2.139 \cdot 10^{-8} \mathrm{~A} / \mathrm{cm}^{2}$.

This indicates that in presence of Roseday $-5 \mathrm{mg}$, the corrosion resistance of SS 316L alloy in artificial saliva increases. Hence people clipped with orthodontic wire made of SS 316L alloy need not hesitate to take Roseday-5 mg orally. 


\section{Implication}

It is concluded that people clipped with orthodontic wire made of SS 316L alloy need not hesitate to take Roseday-5 mg orally.

Analysis of AC impedance spectra

The AC impedance parameters of SS 316L alloy immersed in various test solutions are given in Table 3. The Nyquist plots are shown in Figure 4, Figure 5. The Bode plots are shown in Figures 6 and 7. The charge transfer resistance $\left(R_{\mathrm{t}}\right)$ and double layer capacitance values $\left(C_{\mathrm{dl}}\right)$ are derived from Nyquist plot. The impedance values are derived from Bode plot.

The charge transfer resistance $\left(R_{\mathrm{t}}\right)$ values of SS 316L in artificial saliva in the absence and presence of Roseday- 5 tablet are compared in Table 4 and graphically in Figure 8.

Table 3. Corrosion parameters of SS 316L alloy immersed in artificial saliva (AS) in the absence and presence of Roseday- 5 obtained by AC impedance spectra.

\begin{tabular}{|c|c|c|c|}
\hline System & $\begin{array}{c}R_{\mathrm{t}} \\
\mathrm{Ohm} \cdot \mathrm{cm}^{2}\end{array}$ & $\begin{array}{c}C_{\mathrm{dl}} \\
\mathrm{F} / \mathrm{cm}^{2}\end{array}$ & $\begin{array}{r}\text { Impedance } \\
\log (\mathrm{z} / \text { Ohm })\end{array}$ \\
\hline Artificial saliva & 320260 & $1.5925 \cdot 10^{-11}$ & 5.828 \\
\hline AS + Roseday -5 & 416460 & $1.2246 \cdot 10^{-11}$ & 5.901 \\
\hline
\end{tabular}

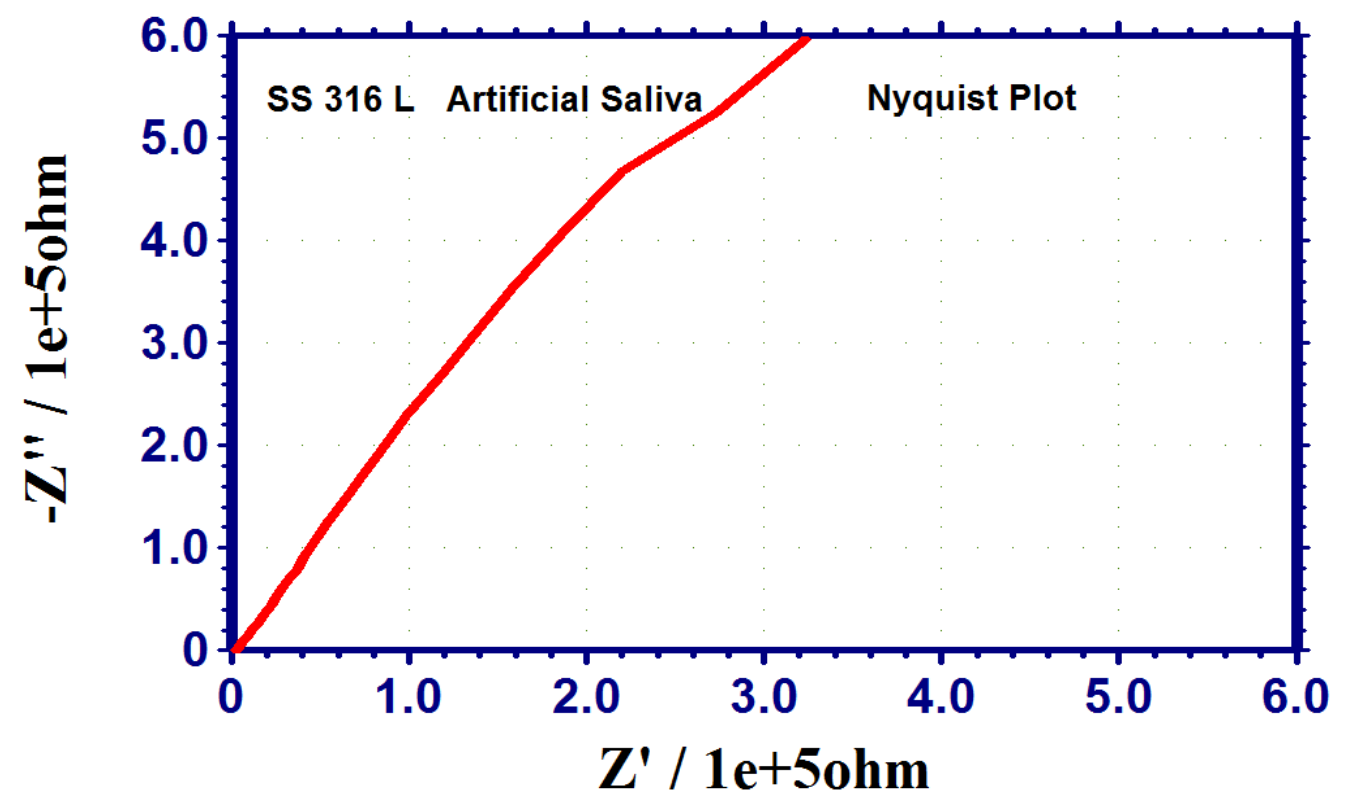

Figure 4. AC impedance spectra of SS 316L alloy immersed in artificial saliva. 


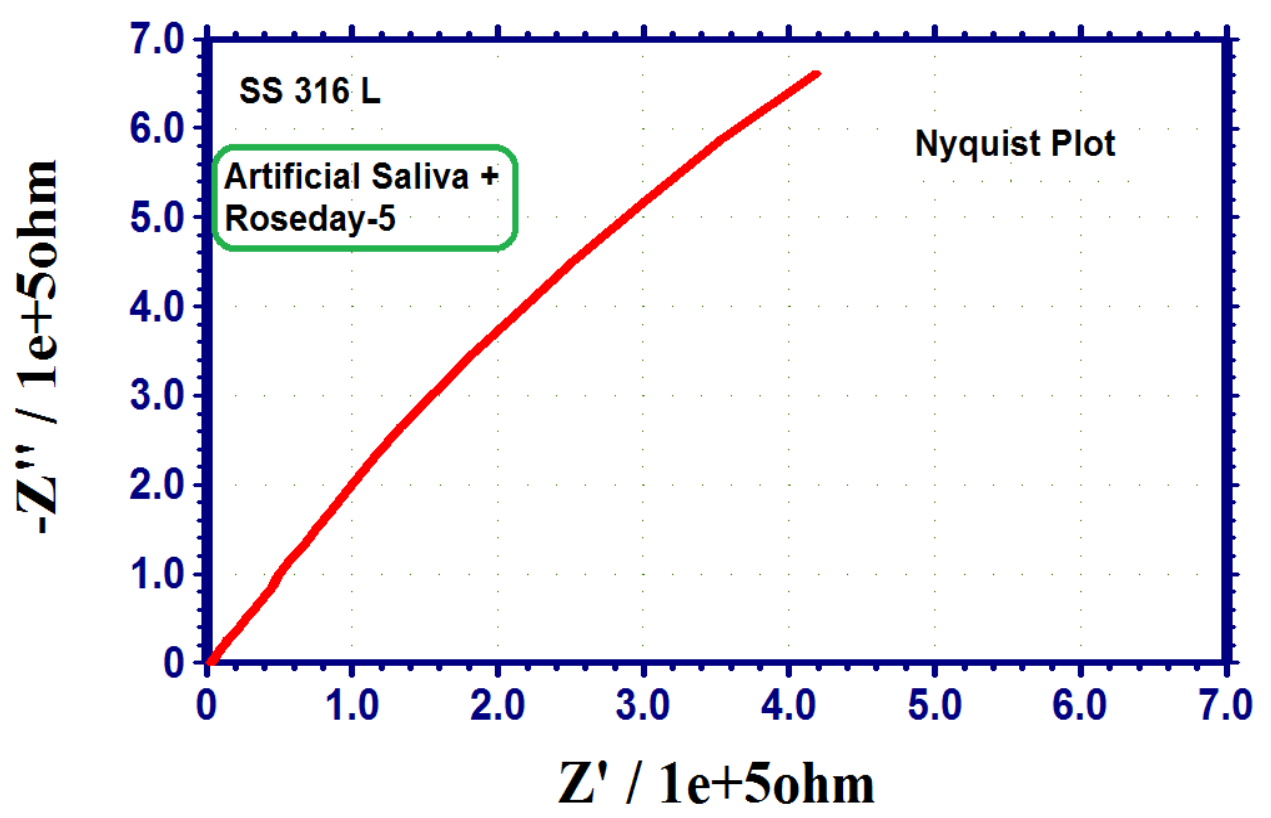

Figure 5. AC impedance spectra of SS 316L alloy immersed in artificial saliva in the presence of Roseday-5.
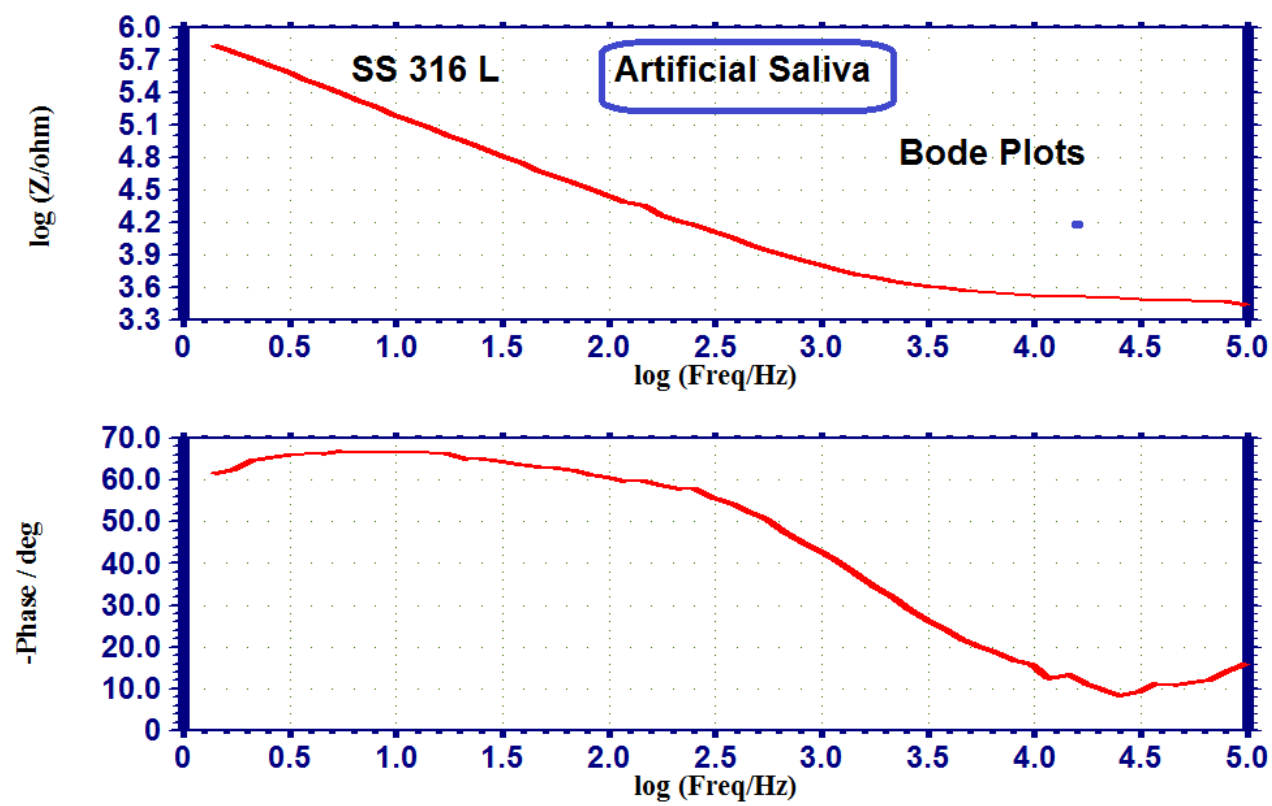

Figure 6. AC impedance spectrum of SS 316L alloy immersed in artificial saliva (Bode plot).

Table 4. Comparison of charge transfer resistance values in the absence and presence of Roseday-5.

\begin{tabular}{cc} 
System & $\begin{array}{c}\boldsymbol{R}_{\mathbf{t}} \\
\mathbf{O h m} \cdot \mathbf{c m}^{\mathbf{2}}\end{array}$ \\
\hline Artificial saliva & 320260 \\
AS +Roseday-5 & 416460
\end{tabular}



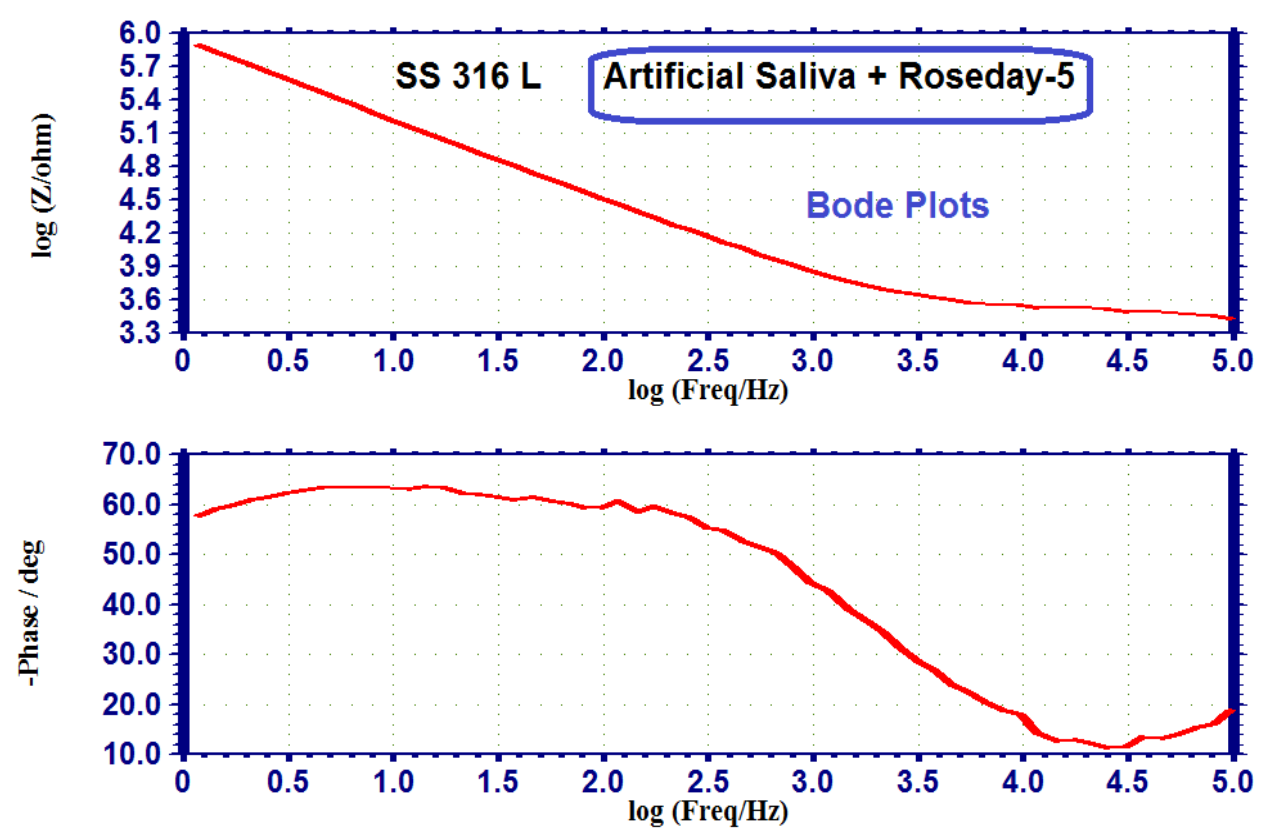

Figure 7. AC impedance spectrum of artificial saliva in the presence of Roseday-5 (Bode Plot).

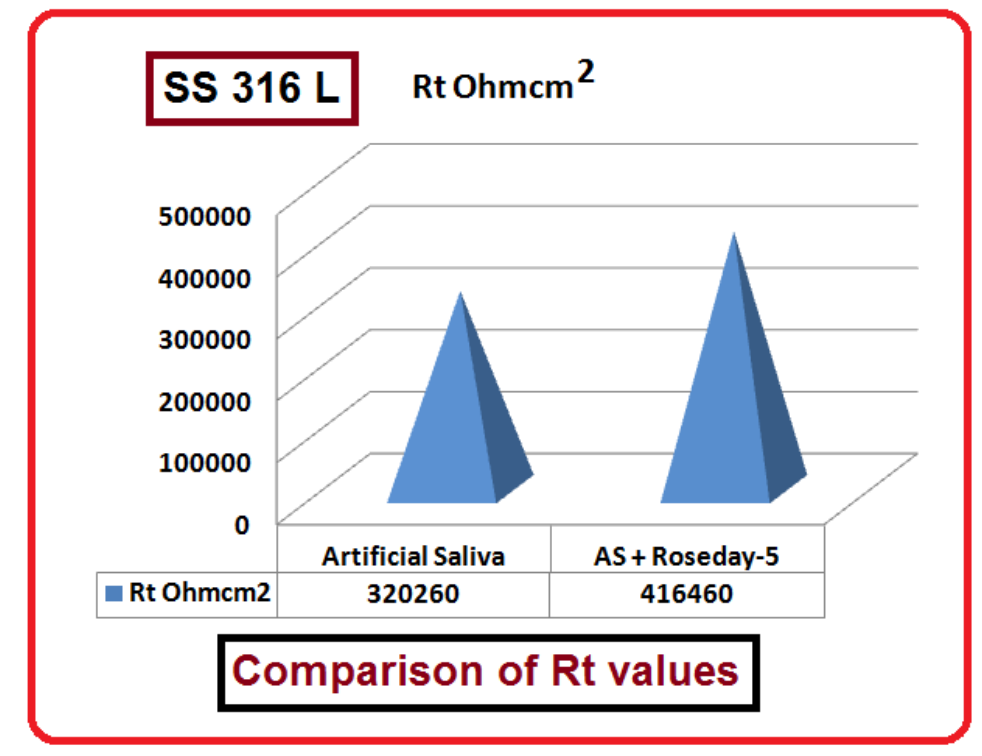

Figure 8. Comparison of charge transfer resistance $\left(R_{\mathrm{t}}\right)$ values of SS 316L alloy in the absence and presence of Roseday- 5 .

When SS 316L alloy is immersed in artificial saliva, $R_{\mathrm{t}}$ (charge transfer resistance) is $320260 \mathrm{Ohm} \cdot \mathrm{cm}^{2} . C_{\mathrm{dl}}$ (double layer capacitance) is $1.5925 \cdot 10^{-11} \mathrm{~F} / \mathrm{cm}^{2}$. Impedance is $5.828 \log Z /$ Ohm. 
Influence of Roseday-5mg as revealed by AC Impedance spectra

When Roseday-5 mg is added to artificial saliva, the $R_{\mathrm{t}}$ (charge transfer resistance) is $416460 \mathrm{Ohm} \cdot \mathrm{cm}^{2}$. $C_{\mathrm{dl}}$ (double layer capacitance) is $1.2246 \cdot 10^{-11} \mathrm{~F} / \mathrm{cm}^{2}$. Impedance is $5.901 \log Z / O h m$. It is observed from the Table 3 that when Roseday-5 mg is added to AS, the $R_{\mathrm{t}}$ value increases from 320260 to $416460 \mathrm{Ohm} \cdot \mathrm{cm}^{2}$. Double layer capacitance decreases from $1.5925 \cdot 10^{-11}$ to $1.2246 \cdot 10^{-11} \mathrm{~F} / \mathrm{cm}^{2}$.

This indicates that in presence of Roseday $-5 \mathrm{mg}$, the corrosion resistance of SS 316L alloy in artificial saliva increases. Hence people clipped with orthodontic wire made of SS 316L alloy need not hesitate to take Roseday-5 mg orally.

\section{Implication}

Based on the results of polarisation study and AC Impedance spectra, it is concluded that people clipped with orthodontic wire made of SS 316L alloy need not hesitate to take Roseday-5mg orally.

\section{Conclusions}

- The corrosion resistance of SS 316L alloy in artificial saliva, in the absence and presence of Roseday-5 mg has been evaluated by polarization study and AC impedance spectra.

- Polarisation study reveals that in the presence of Roseday-5 mg, $L P R$ value increases and corrosion current decreases.

- That is, in presence of Roseday-5 mg, the corrosion resistance of SS 316L alloy in artificial saliva increases.

- AC impedance study reveals that in the presence of Roseday-5 mg, $R_{\mathrm{t}}$ value increases and $C_{\mathrm{dl}}$ decreases.

- That is in the presence of Roseday-5 mg the corrosion resistance of SS 316L alloy in AS increases.

- It is concluded that people clipped with orthodontic wire made of SS $316 \mathrm{~L}$ alloy need not hesitate to take Roseday-5 mg orally.

\section{Acknowledgment}

The authors are thankful to their respective managements for their help and encouragement. Special thanks to Rev. Dr. Antony Pushpa Ranjitham (Superior General), Rev. Sr. Thanaseeli Sengole (Asst. General), Rev.Sr.M. Margaret Inbaseeli (College Secretary), Rev. Dr. Pramila (Principal), Rev. Sr. Gnana Soundari (Provincial) and Mrs J.Antony Justina Mary (Vice Principal) for their Prayer and Blessings. 


\section{References}

1. V.A. Brigitta, C. Thangavelu and S. Rajendran, Effects of Tablet on Orthodontic Wire made of SS 316L Alloy in Artificial Saliva, Int. J. Res. Anal. Rev., 2019, 6, 10001005 .

2. A. Anandan, S. Rajendran, J. Sathiya Bama and D. Sathiya Raj, Influence of some tablets on corrosion resistance of orthodontic wires made of SS 316L alloy in artificial saliva, Int. J. Corros. Scale Inhib., 2017, 6, no. 2, 132-141. doi: 10.17675/2305-68942017-6-2-3

3. R. D'souza, A. Chattree and S. Rajendran, Corrosion Resistance of SS 316L alloy in Artificial Saliva in presence of Sparkle fresh Toothpaste, Port. Electrochim. Acta, 2017, 35, 339-350. doi: 10.4152/pea.201706339

4. V.A. Brigitta, C. Thangavelu and S. Rajendran, Corrosion resistance of SS18/8, Gold 18 carat, Gold 22 carat and SS 316L alloy in artificial saliva in the absence and presence of Vitavion Fort tablet $500 \mathrm{mg}$, Eur. J. Biomed. Pharm. Sci., 2018, 5, 864-871.

5. R. Saranya and S. Rajendran, Influence of D-glucose on corrosion resistance of SS 316L in presence of artificial saliva, Rasayan J. Chem., 2018, 11, 103-110. doi: 10.7324/RJC.2018.1111747

6. Z. Chao, X. Yaomu, L. Chufeng and L. Conghua, The effect of mucin, fibrinogen and IgG on the corrosion behaviour of Ni-Ti alloy and stainless steel, BioMetals, 2017, 30, 367-377. doi: 10.1007/s10534-017-0012-3

7. J. Kamiński, K. Małkiewicz, J. Rębiś and T. Wierzchoń, The effect of glow discharge nitriding on the corrosion resistance of stainless steel orthodontic arches in artificial saliva solution, Arch. Metall. Mater., 2020, 65, 375-384. doi: 10.24425/amm.2020.131740

8. E. Erwansyah and C. Susilowati, The effect of snake fruit extract (Salacca zalacca) in inhibiting the release of chromium $(\mathrm{Cr})$ and nickel $(\mathrm{Ni})$ ion from stainless steel orthodontic wire to saliva, Int. J. Appl. Pharm., 2019, 11, 33-36. doi: 10.22159/ijap.2019.v11s4.35286

9. I.M. Trolic, N.L. Serdarevic, Z. Todoric, A. Budimir, S. Spalj and H.O. Curkovic, Corrosion of orthodontic archwires in artificial saliva in the presence of Lactobacillus reuteri, Surf. Coat. Technol., 2019, 370, 44-52. doi: 10.1016/j.surfcoat.2019.04.081

10. N. Simionescu, A. Ravoiu and L. Benea, Electrochemical in vitro properties of 316L stainless steel for orthodontic applications, Rev. Chim. (Bucharest, Rom.), 2019, 70, 1144-1148. doi: 10.37358/RC.19.4.7081

11. https://www.practo.com/medicine-info/roseday-5-mg-tablet-9901

12. N.Y.S. Diki, K.V. Bohoussou, M.G.-R. Kone, A. Ouedraogo and A. Trokourey, Cefadroxil Drug as Corrosion Inhibitor for Aluminum in $1 \mathrm{M} \mathrm{HCl} \mathrm{Medium:}$ Experimental and Theoretical Studies, IOSR J. Appl. Chem., 2018, 11, 24-36. doi: $\underline{10.9790 / 5736-1104012436}$ 
13. H. Lgaz, R. Salghi and I.H. Ali, Corrosion Inhibition Behaviour of 9Hydroxyrisperidone as a Green Corrosion Inhibitor for Mild Steel in Hydrochloric Acid: Electrochemical, DFT and MD Simulations Studies, Int. J. Electrochem. Sci., 2018, 13, 250-264. doi: $10.2964 / 2018.01 .26$

14. H. Lgaz, R. Salghi, A. Chaouiki, Shubhalaxmi, S. Jodeh and K. Subrahmanya Bhat, Pyrazoline derivatives as possible corrosion inhibitors for mild steel in acidic media: A combined experimental and theoretical approach, Cogent Eng., 2018, 5, 1-17. doi: $\underline{10.1080 / 23311916.2018 .1441585}$

15. R.J. Tuama, M.E. Al Dokheily and M.N. Khalaf, Recycling and evaluation of poly(ethylene terephthalate) waste as effective corrosion inhibitors for C-steel material in acidic media, Int. J. Corros. Scale Inhib., 2020, 9, no. 2, 427-445. doi: 10.17675/23056894-2020-9-2-3

16. A.H. Al-Moubaraki and H. Awaji, 1-X-4-[4'-(-OCH$)-$ Styryl] pyridinium iodides, potent inhibitors for stainless steel corrosion in $2 \mathrm{M} \mathrm{HCl}$ acid solutions, Int. J. Corros. Scale Inhib., 2020, 9, no. 2, 460-501. doi: 10.17675/2305-6894-2020-9-2-5

17. G. Fekkar, F. Yousfi, H. Elmsellem, M. Aiboudi, M. Ramdani, I. Abdel-Rahman, B. Hammouti and L. Bouyazza, Eco-friendly Chamaerops humilis L. fruit extract corrosion inhibitor for mild steel in $1 \mathrm{M} \mathrm{HCl}$, Int. J. Corros. Scale Inhib., 2020, 9, no. 2, 446-459. doi: 10.17675/2305-6894-2020-9-2-4

18. W.M.K.W.M. Ikhmal, M.Y.N. Yasmin, M.F.F. Maria, S.M. Syaizwadi, W.A.W. Rafizah, M.G.M. Sabri and B.M.Zahid, Evaluating the performance of Andrographis paniculata leaves extract as additive for corrosion protection of stainless steel 316L in seawater, Int. J. Corros. Scale Inhib., 2020, 9, no. 1, 118-133. doi: 10.17675/2305-6894-2020-9-1-7

19. A. Boumezzourh, M. Ouknin, E. Chibane, J. Costa, A. Bouyanzer, B. Hammouti and L. Majidi, Inhibition of tinplate corrosion in $0.5 \mathrm{M} \mathrm{H}_{2} \mathrm{C}_{2} \mathrm{O}_{4}$ medium by Mentha pulegium essential oil, Int. J. Corros. Scale Inhib., 2020, 9, no. 1, 152-170. doi: 10.17675/2305$\underline{6894-2020-9-1-9}$ 